\section{Influence of genetic polymorphisms and mutations in the cardiac pathology of iron overload in thalassemia and sickle cell anemia patients: a retrospective study}

Veronica Agrigento, ${ }^{1}$

Giuseppina Calvaruso, ${ }^{1}$ Serena Sclafani, ${ }^{1}$

Aurelio Maggio,' Valeria Lo Nigro, ${ }^{2}$ Elena D'Alcamo'

${ }^{1}$ Azienda Ospedali Riuniti Villa

Sofia-Cervello, Ospedale V. Cervello UOC

Ematologia per le Malattie Rare del

Sangue e degli Organi Ematopoietici,

Palermo; ${ }^{2}$ Dipartimento di Scienze

Statistiche e Matematiche Università

degli Studi di Palermo, Italy

\section{Abstract}

Cardiac disease in thalassemia is determined by the accumulation of iron in the tissue. Genetic factors could influence the severity and the rapidity of the modifications of the cardiac tissue. Mutations or polymorphisms of genes have already been described as being implicated in cardiac disease. In particular, we studied the polymorphisms C1091T in the Connexin 37 gene (CX 37), 4G -668 5G in the Plasminogen Activator Inhibitor-1 gene (PAI 1) and $5 \mathrm{~A}-11716 \mathrm{~A}$ in the Stromelysin-1gene $(S L)$ in 193 randomly selected patients affected by hemoglobinopathies and 100 normal subjects randomly selected from the general population. A retrospective analysis based on history, clinical data and imaging studies was carried out to assess the presence and type of heart disease. The results of our study do not demonstrate a close association between polymorphism in these candidate genes and cardiac disease, and in particular with myocardial infarction in a cohort of Sicilian patients affected by hemoglobinopathies.

\section{Introduction}

Myocardial infarction is a multifactorial and polygenic disorder that is thought to result from an interaction between a person's genetic makeup and various environmental factors. ${ }^{1,2}$ Cardiac complications are very frequent in thalassemia patients in whom chronic anemia and progressive iron deposition in the heart are the major causes of morbidity and mortality.

The pathophysiology of the disorder is mul- tifactorial, with myocardial iron overload playing a central role and immune-inflammatory mechanisms also making a significant contribution.

Myocarditis etiology plays an important role in a number of cases of myocardial impairment in patients with thalassemia, although the genetic factors cannot be underestimated. Epidemiological studies have suggested that genetic mutations and polymorphisms are potentially involved in the mechanisms of heart disease. ${ }^{3}$

Economus et al. demonstrated the influence of a particular allele of the apolipoprotein $\mathrm{E}$ $(A p o E)$ gene on myocardial dysfunction. In fact, the $A p o E 4$ allele may represent an important genetic risk factor for the development of organ damage in homozygous beta-thalassemia. ${ }^{4}$

The development of cardiac disease in thalassemia is determined by the rate of accumulation of iron in the tissue. In addition, genetic factors could influence the severity and the rapidity of the modifications of the cardiac tissue. Indeed, mutations or polymorphisms in the genes have already been described as factors involved in cardiac disease.

Three candidate genes particularly related to the risk of myocardial infarction were selected: the Plasminogen Activator Inhibitor-1 (PAI1), the Connexin 37 gene and Stromelysin- $1 .{ }^{5}$

Plasminogen Activator Inhibitor-1 (PAI-1) is the major inhibitor of fibrinolysis. When PAI-1 is high, fibrinolytic activity is depressed, and there is increased risk for arterial and venous thrombosis. PAI-1 is a significant, independent risk factor for coronary artery disease and ischemic stroke. The 4G allele of a recently described common 4/5 Guanine tract (4G/5G) polymorphism in the $P A I-1$ gene promotor region is associated with higher plasma PAI-1 activity. ${ }^{6}$ In vitro experiments have shown that both alleles of the $4 \mathrm{G} / 5 \mathrm{G}$ polymorphism contain a binding site for a transcription activator, and that the $5 \mathrm{G}$ allele also contains a binding site for a transcription repressor that partially overlaps with the activator binding site. ${ }^{7}$ Therefore, the $4 \mathrm{G}$ allele of the PAI-1 gene is associated with increased basal gene transcription. The 4G/4G genotype of PAI- 1 has been shown to be associated with ischemic heart disease and myocardial infarction (MI). ${ }^{8}$

Connexin 37 is a component of gap junctions, which are composed of arrays of intercellular channels that provide a route for the diffusion of low molecular weight materials from cell to cell. Mutations in this gene have been associated with atherosclerosis and a higher risk of myocardial infarction. The C1019-T polymorphism in CX37 may provide a single gene marker, which could be useful in assessing atherosclerotic plaque development, particularly in cardiovascular risk groups, such as those with borderline hypertension. ${ }^{9}$
Correspondence: Elena D'Alcamo, A.O.R Villa Sofia Cervello, via Trabucco 180, 90146- Palermo, Italy. Tel. +39.091.680276 - Fax: +39.091.6880828. E-mail: talelmar@virgilio.it

Key words: heart disease, PAI-1, stromelysin, connexin 37.

Acknowledgments: this research was supported by health regional project T13/15. The authors would like to thank the "Piera Cutino" Association and Foundation for Research for its continuous support.

Conflict of interests: the authors declare no potential conflict of interests.

Received for publication: 27 July 2012

Revision received: 18 October 2012.

Accepted for publication: 22 October 2012.

This work is licensed under a Creative Commons Attribution 3.0 License (by-nc 3.0).

(O) Copyright V. Agrigento et al., 2012

Licensee PAGEPress, Italy

Thalassemia Reports 2012; 2:e3

doi:10.4081/thal.2012.e3

Stromelysin-1 is a key member of the matrix metalloproteinase (MMP) family, with a broad substrate specificity. It can degrade types II, IV, and IX collagen, proteoglycans, laminin, fibronectin, gelatin, and elastin. In addition, stromelysin-1 can also activate other MMPs, such as collagenase, matrilysin, and gelatinase B, making stromelysin-1 crucial to connective tissue remodeling. Expression of stromelysin-1 is primarily regulated at the level of transcription, where the promoter of the gene responds to various stimuli, including growth factors, cytokines, tumor promoters, and oncogene products. There is a common polymorphism in the promoter sequence at position -1171 of the human stromelysin-1 gene, with one allele having a run of six adenosines $(6 \mathrm{~A})$ and the other five adenosines (5A). A 5A/6A promoter polymorphism can regulate the transcription of the stromelysin-1 gene in an allele-specific manner. Evidence has been presented that the $6 \mathrm{~A}$ allele is associated with the progression of coronary heart disease (CHD). In contrast, the $5 \mathrm{~A}$ allele may be linked to the risk of myocardial infarction. ${ }^{10}$

The aim of this study is to identify the genetic polymorphisms and mutations that confer susceptibility to myocardial infarction in patients affected by hemoglobinopathies. We investigated a group of patients with thalassemia major, thalassemia intermedia, and sickle cell anemia, and normal subjects selected from the general population. 


\section{Materials and Methods}

\section{Patients}

We analyzed the three candidate genes (4G/5G PAI1, 5A/6A -1711 SL and C1019T) in 193 randomly selected patients referred to our center; 74 had thalassemia major, 68 thalassemia intermedia, and 51 sickle cell anemia. We also analyzed 100 normal subjects (53\% female, mean age 36 years) randomly selected from the general population as control. Clinical, laboratory and instrumental data are shown in Table 1. All patients with thalassemia major were regularly transfused and underwent chelation therapy. Among the 68 patients with thalassemia intermedia, only 13 were receiving regular transfusions and 12 occasional transfusions. The remaining $43 \mathrm{had}$ never been transfused, and only 34 were receiving regular chelation therapy. Of the 51 patients with sickle cell anemia, only 10 were regularly transfused, 5 occasionally; 35 had never been transfused and only 15 received regularly chelation therapy. No statistically significant difference was found as regards sex, age, mean hemoglobin ( $\mathrm{Hb})$, and heart $\mathrm{T}^{*}$ between the three groups of patients studied ( $P>0.05)$. A statistically significant difference was, however, found for the average amount of blood transfused, as well as the mean ferritin level between the three groups $(\mathrm{P}<0.05)$.

\section{Molecular analysis}

Genomic DNA was extracted from mononuclear cells of peripheral blood samples by using a phenol-chloroform method. Polymerase chain reaction (PCR) was carried out in a total volume of $100 \mu \mathrm{L}$ containing $1 \mu \mathrm{gr}$ genomic DNA, $200 \mu \mathrm{M}$ of oligonucleotides specific primers, $200 \mu \mathrm{M}$ of dNTPs, $2 \mathrm{mM} \mathrm{MgCl}_{2}, 1 \mathrm{X}$ buffer and $2.5 \mathrm{U}$ Taq polymerase. The thermal cycling conditions for the PAI 1 were: $30 \mathrm{~min}$ at $94^{\circ} \mathrm{C}, 55 \mathrm{~min}$ at $30^{\circ} \mathrm{C}$, one min at $72^{\circ} \mathrm{C}$, repeated for 30 cycles. PCR products were electrophoresed in a $3 \%$ agarose gel and visualized by ethidium bromide staining. The thermal cycling condition for the CX37 were: $30 \mathrm{~min}$ at $96^{\circ} \mathrm{C}, 15 \mathrm{~min}$ at $60^{\circ} \mathrm{C}, 4 \mathrm{~min}$ at $72^{\circ} \mathrm{C}$, repeated for 30 cycles; and PCR products were DrdI digested at $37^{\circ} \mathrm{C}$ overnight and analyzed by agarose gel electrophoresis. The thermal cycling condition for the SL were: one min at $93^{\circ} \mathrm{C}$, one min at $55^{\circ} \mathrm{C}$, one min at $72^{\circ} \mathrm{C}$, repeated for 30 cycles. The polymorphism $5 \mathrm{~A} / 6 \mathrm{~A}$ at -1171 in the stromelysin 1 gene was analyzed by reverse dot blot hybridization or, alternatively, PCR fragments were analyzed by the direct sequencing method using a Big Dye terminator 3.1 cycle sequencing kit and run on an ABI PRISM 3130 DNA analyzer.

\section{Cardiological data analysis}

Anamnestic, clinical and instrumental data were collected for analysis.

Instrumental investigations were evaluated on the electrocardiogram (ECG), echocardiography, ECG-holter and magnetic resonance imaging T2* (MRI) to evaluate iron overload.

\section{Statistical analysis}

The measurable variables were compared between the patients and controls affected by hemoglobinopathies selected from the general population using logistical regression analysis. $\mathrm{P}<0.05$ was considered statistically significant.
To assess the relation of genetic polymorphism, specifically as regards PAI-1,SL and CX37, to the severity and the rapidity of development of heart disease, three logistical regression models were created. These were based on the three different patients' group: thalassemia major, thalassemia intermedia, and sickle cell disease. For each group, differences between the levels of the explanatory variables were evaluated using the Wald test compared with the standard normal distribution. The level of significance for each parameter was set at $\mathrm{P}<0.05$ and the following levels made up the baseline subset: $P A I$ 1=4G/4G; $S L=5 \mathrm{~A} / 5 \mathrm{~A} ; C X 37=$ =homozygote.

Table 1. Clinical, laboratory and instrumental data of the patients studied.

\begin{tabular}{lccc} 
Findings & $\begin{array}{c}\text { Thalassemia } \\
\text { major }\end{array}$ & $\begin{array}{c}\text { Thalassemia } \\
\text { intermedia }\end{array}$ & $\begin{array}{c}\text { Sickle cell } \\
\text { anemia }\end{array}$ \\
No. patients (total 193) & 74 & 68 & 51 \\
Females (\%) & $55.5 \%$ & $51.5 \%$ & $49 \%$ \\
\hline Age (years) & $35.28 \pm 10.6$ & $44.13 \pm 15.35$ & $45.27 \pm 12.13$ \\
Mean ferritin (ng/mL) & $1574.76 \pm 1116$ & $556.97 \pm 394.15$ & $558.88 \pm 508.67$ \\
\hline Hb mean (gr/dL) & $9.8 \pm 0.74$ & $9.31 \pm 1.15$ & $10.06 \pm 1.26$ \\
Blood transfused annually (L) & $177.11 \pm 57.94$ & $95.05 \pm 36.95$ & $84.02 \pm 27.45$ \\
\hline Splenectomy, \% (no.) & $45 \%(34)$ & $57.3 \%(39)$ & $42 \%(21)$ \\
CMR T2* heart (mean) & $32.84 \pm 10.56 \mathrm{~ms}$ & $33.38 \pm 7.84 \mathrm{~ms}$ & n.a. \\
\hline
\end{tabular}

$\mathrm{Hb}$, hemoglobin; CMR, cardiac magnetic resonance imaging; n.a., not available.

Table 2. Results of molecular analysis of the PAI, CX37 and SL genes.

\begin{tabular}{|c|c|c|c|c|c|c|c|c|c|c|}
\hline & $\begin{array}{l}\text { No. } \\
\text { amples }\end{array}$ & $4 G / 4 G$ & $\begin{array}{c}\text { PAI } \\
4 G / 5 \mathrm{G}\end{array}$ & $\mathrm{G} / 5 \mathrm{G}$ & Norm. & $\begin{array}{l}\text { CX37 } \\
\text { Heter. }\end{array}$ & Homoz. & $5 \mathrm{~A} / 5 \mathrm{~A}$ & $\begin{array}{c}\text { SL } \\
5 \mathrm{~A} / 6 \mathrm{~A}\end{array}$ & $6 \mathrm{~A} / 6 \mathrm{~A}$ \\
\hline $\begin{array}{l}\text { Thalassemia } \\
\text { major, \% (no.) }\end{array}$ & 74 & $\begin{array}{c}24.4 \% \\
(18)\end{array}$ & $\begin{array}{c}52.7 \% \\
(39)\end{array}$ & $\begin{array}{c}22.9 \% \\
(17)\end{array}$ & $\begin{array}{c}47.3 \% \\
(35)\end{array}$ & $\begin{array}{c}37.8 \% \\
(28)\end{array}$ & $\begin{array}{c}14.9 \% \\
(11)\end{array}$ & $\begin{array}{l}14.9 \% \\
(11)\end{array}$ & $\begin{array}{c}52.7 \% \\
(39)\end{array}$ & $\begin{array}{c}32.4 \% \\
(24)\end{array}$ \\
\hline $\begin{array}{l}\text { Thalassemia } \\
\text { intermedia, } \\
\% \text { (no.) }\end{array}$ & 68 & $\begin{array}{c}20.6 \% \\
(14)\end{array}$ & $\begin{array}{c}48.5 \% \\
(33)\end{array}$ & $\begin{array}{c}30.9 \% \\
(21)\end{array}$ & $\begin{array}{l}41 \% \\
(28)\end{array}$ & $\begin{array}{l}43 \% \\
(29)\end{array}$ & $\begin{array}{l}16 \% \\
(11)\end{array}$ & $\begin{array}{l}6 \% \\
\text { (4) }\end{array}$ & $\begin{array}{l}68 \% \\
(46)\end{array}$ & $\begin{array}{l}26 \% \\
(18)\end{array}$ \\
\hline $\begin{array}{l}\text { Sickle cell } \\
\text { anemia, } \\
\% \text { (no.) }\end{array}$ & 51 & $\begin{array}{c}31.3 \% \\
(16)\end{array}$ & $\begin{array}{l}51 \% \\
(26)\end{array}$ & $\begin{array}{c}17.7 \% \\
(9)\end{array}$ & $\begin{array}{l}31 \% \\
(16)\end{array}$ & $\begin{array}{l}57 \% \\
(29)\end{array}$ & $\begin{array}{c}12 \% \\
(6)\end{array}$ & $\begin{array}{c}25.5 \% \\
(13)\end{array}$ & $\begin{array}{l}45 \% \\
(23)\end{array}$ & $\begin{array}{c}29.5 \% \\
(15)\end{array}$ \\
\hline $\begin{array}{l}\text { Controls, } \\
\% \text { (no.) }\end{array}$ & 100 & $\begin{array}{l}34 \% \\
(34)\end{array}$ & $\begin{array}{l}29 \% \\
(29)\end{array}$ & $\begin{array}{l}37 \% \\
(37)\end{array}$ & $\begin{array}{l}41 \% \\
(41)\end{array}$ & $\begin{array}{l}42 \% \\
(42)\end{array}$ & $\begin{array}{l}17 \% \\
(17)\end{array}$ & $\begin{array}{l}32 \% \\
(32)\end{array}$ & $\begin{array}{l}37 \% \\
(37)\end{array}$ & $\begin{array}{l}31 \% \\
(31)\end{array}$ \\
\hline
\end{tabular}

Norm., normal controls; Heter., heterozygote; Homoz., homozygote.

Table 3. $P$ values calculated for the polymorphism between patients with and without heart disease.

\begin{tabular}{|c|c|c|c|c|c|c|c|c|c|}
\hline \multirow[t]{2}{*}{ Polymorphisms } & \multicolumn{3}{|c|}{$\begin{array}{l}\text { Thalassemia } \\
\text { major } \\
n=74\end{array}$} & \multicolumn{3}{|c|}{$\begin{array}{c}\text { Thalassemia } \\
\text { intermedia } \\
n=68 \\
\text { Heart disease }\end{array}$} & \multicolumn{3}{|c|}{$\begin{array}{c}\text { Sickle cell } \\
\text { anemia } \\
n=51\end{array}$} \\
\hline & $\begin{array}{c}\text { No } \\
\mathrm{n}=52\end{array}$ & $\begin{array}{c}\text { Yes } \\
\mathrm{n}=22\end{array}$ & $\mathbf{P}$ & $\begin{array}{c}\text { No } \\
\mathrm{n}=56\end{array}$ & $\begin{array}{c}\text { Yes } \\
n=12\end{array}$ & $P$ & $\begin{array}{c}\text { No } \\
\mathrm{n}=47\end{array}$ & $\begin{array}{c}\text { Yes } \\
n=4\end{array}$ & $\mathbf{P}$ \\
\hline PAI: $4 \mathrm{G} / 4 \mathrm{G}$ & 15 & 3 & 0.17 & 12 & 1 & 0.30 & 15 & 1 & 0.90 \\
\hline CX37: Homozygote & 8 & 3 & 0.85 & 8 & 3 & 0.40 & 5 & 1 & 0.61 \\
\hline SL: $5 \mathrm{~A} / 5 \mathrm{~A}$ & 8 & 3 & 0.77 & 4 & 0 & 0.99 & 13 & 0 & 0.99 \\
\hline
\end{tabular}




\section{Results}

The results of molecular analysis of the PAI, CX37 and $S L$ genes are shown in Table 2. A group of patients with thalassemia major, thalassemia intermedia, sickle cell anemia and normal subjects froma Sicilian population were classified according to the presence of 4G/5G polymorphism of PAI-1 Gene Promoter, C1019T polymorphism of connexin (CX 37) and $5 \mathrm{~A} / 6 \mathrm{~A}$ polymorphism of stromelysin. In the thalassemia major group, 22 patients suffered from heart disease: one hypertensive heart disease without heart failure, 7 dilated/restrictive cardiomyopathy, 10 had arrhythmia, and 4 patients had heart failure. The distribution of PAI 1, SL and CX37 genotypes for this group are, respectively: three $4 \mathrm{G} / 4 \mathrm{G}$ (13.6\%), thirteen 4G/5G (59.0\%), six 5G/5G (27.4\%); three $5 \mathrm{~A} / 5 \mathrm{~A}(13.6 \%)$ twelve $5 \mathrm{~A} / 6 \mathrm{~A}(54.5 \%)$, seven $6 \mathrm{~A} / 6 \mathrm{~A}$ (31.8\%); nine normal (40.9\%), three homozygotes (13.6\%) and ten heterozygous (45.4\%). In the thalassemia intermedia group, 12 patients had heart disease: 2 with myocardial infarction, 2 hypertensive heart disease without heart failure, 4 dilated/restrictive cardiomyopathy, and 4 patients with arrhythmia. The distribution of PAI 1, SL and CX37 genotypes for this group are, respectively: one 4G/4G (8.3\%), five 4G/5G (41.6\%), six 5G/5G (50.0\%), eight $5 \mathrm{~A} / 6 \mathrm{~A}(66.6 \%)$, four $6 \mathrm{~A} / 6 \mathrm{~A}$ (33.3\%); one normal (8.3\%), three homozygotes (25\%) and eight heterozygous (66.6\%). In sickle cell disease group, 4 patients had heart disease: one dilated/restrictive cardiomyopathy, 2 heart failure, and one with myocardial infarction. The distribution of PAI 1, SL and $C X 37$ genotypes for this group are, respectively: one 4G/4G (25\%), three 4G/5G (75\%), two $5 \mathrm{~A} / 6 \mathrm{~A}$ (50\%), $26 \mathrm{~A} / 6 \mathrm{~A}$ (50\%); three homozygotes (75\%) and one heterozygous (25\%). P values calculated for the polymorphism between patients with and without heart disease are shown in Table 3.

\section{Conclusions}

Cardiac failure and serious arrhythmias are the major causes of life-threatening morbidity and mortality in iron-overload patients..$^{11,12}$ Heart disease is mainly expressed by a particular cardiomyopathy that progressively leads to heart failure and death. The thalassemia cardiomyopathy is mainly characterized by 2 dis- tinct phenotypes: a dilated phenotype, with left ventricular dilatation and impaired contractility, and a restrictive phenotype, with restrictive left ventricular filling, pulmonary hypertension, and right heart failure. In accordance with literature data, our data show that, in our cohort of patients, the most common types of heart disease are dilated/restrictive cardiomyopathy and arrhythmia. The results of our study do not support the concept of a close association between polymorphism in the three candidate genes and heart disease in our cohort of patients affected by hemoglobinopathies. However, this genetic polymorphism does not seem to influence the severity and the rapidity of heart disease. In fact, as shown in Table 3 , none of the $P$ values showed a significant statistical difference $(\mathrm{P}>0.05)$. Different epidemiological studies have suggested the several genetic variants increase also the risk of myocardial infarction. Yamada et al. indicate that the identification of genotype of plasminogen activator inhibitor type 1, stromelysin 1 and connexin 37 can be a reliable means of predicting risk of myocardial infarction, though literature data are controversial. ${ }^{13}$ In our cohort of patients, only 3 (2 with thalassemia intermedia, one with sickle cell anemia) had a history of myocardial infarction; no association between polymorphisms in the $S L$ and $P A I 1$ genes was found in any of these 3 patients. However, 2 of these 3 were homozygous for the C1091T polymorphismin the CX37 gene, although such small numbers of patients with myocardial infarction rather limit interpretation of the data.

In conclusion, the lack of correlation between heart disease and the polymorphisms studied could be because there is no correlation or could be due to the small number of samples analyzed. Consequently, this should be considered a preliminary study. Data from a larger sample of patients could better define the correlation between genetic polymorphisms and heart disease.

\section{References}

1. Marenberg ME, Risch N, Berkman LF, et al. Genetic susceptibility to death from coronary disease in a study of twins. NEnglJ Med 1994;330:1041.

2. Nora JJ, Lortscher RH, Spangler RD, et al. Genetic-epidemiologic study of early-onset ischemic heart disease. Circulation
1980;61:503-8.

3. YamadaY, Izawa H, Ichihara $\mathrm{S}$, et al. Prediction of the risk of myocardial infarction from polymorphisms in candidate genes. N Engl J Med 2002;347:1916-23.

4. Economou-Peterson E, Aessopos A, Kladi A, et al. Apolipoprotein E e 4 allele as a genetic risk factor for left ventricular failure in homozygous $\beta$ thalassemia. Blood 1998;92:3455.

5. Dawson SJ, Wiman B, Hamsten A, et al. The two allele sequences of a common polymorphism in the promotor of the plasminogen activator inhibitor-1 (PAl-1) gene respond differently to interleukin-l in HepG2 cells. J Biol Chem 1993;268: 1073945.

6. Eriksson P, KallinB, van't Hooft FM, et al.Allele-specific increase in basal transcription of the plasminogen activator inhibitor-1 gene is associated with myocardial infarction. Proc Natl Acad Sci USA 1995;92:1851-5.

7. Kim HS, Hwang KY, Chung IK, et al. Tissue plasminogen activator and plasminogen activator inhibitor type 1 gene polymorphism in patients with gastric ulcer complicated with bleeding.J Korean Med Sci 2003;18:58-64.

8. Boerma M, Forsberg L, Van Zeijl L, et al. A genetic polymorphism in connexin 37 as a prognostic marker for atherosclerotic plaque development. J Intern Med 1999; 246:211-8.

9. Schwarz A, Haberbosch W, Tillmanns H, Gardemann A. The stromelysin-1 5A/6A promoter polymorphism is a disease marker for the extent of coronary heart disease. Dis Markers 2002;18:121-8.

10. Ye S, Eriksson P, Hamsten A, et al. Progression of coronary atherosclerosis is associated with a common genetic variant of the human stromelysin-1 promoter which results in reduced gene expression. J Biol Chem 1996;271:13055-60.

11. Rachmilewitz AE, Giardina PJ. How I treat thalassemia. Blood 2011;118:3479-88.

12. Modell B, Khan M, Darlison M. Survival in betathalassaemia major in the UK: data from the UK Thalassaemia Register. Lancet 2000;355:2051-2.

13. Roest M, van der Schouw YT, Banga JD, et al. Plasminogen activator inhibitor 4G polymorphism is associated with decreased risk of cerebrovascular mortality in older women. Circulation 2000;101: 67-70. 